\title{
Neiti Etsivä ja väärennettyjen kirjojen arvoitus
}

\section{Sanna Nyqvist ja Outi Oja, Kirjalliset väärennökset. Huijauksia, plagiaatteja ja luovia lainauksia. Helsinki, Gaudeamus 2018, $381 \mathrm{s.}$}

Outi Ojan ja Sanna Nyqvistin Kirjalliset väärennökset. Huijauksia, plagiaatteja ja luovia lainauksia (2018) lähestyy kirjallisuutta ja kirjallisuusinstituutiota tuoreesta näkökulmasta. Teos käsittelee kirjallisia vääryyksiä, kirjallisuusinstituution valtasuhteita sekä tekijyys- ja kirjallisuuskäsityksiä tavalla, joka tempaa lukijan mukaansa kuin parhaimmat Neiti Etsivät. Teoksen lukijalle kerrotaan johtolangoista, jotka vievät väärentäjien ja huijaajien jäljille sekä hienovaraisista tutkimusmenetelmistä, joilla voidaan analysoida plagioiduiksi epäiltyjen teosten omaperäisyyden astetta. Kirjallisissa väärennöksissä esitellyt kirjailijat ja teokset ovat suurimmaksi osaksi laajalle yleisölle tuttuja. Tekijöiden huolellisen lähdetyön vuoksi myös kirjallisuuskeskusteluja tiiviisti seurannut lukija saa uutta, kriittisesti esitettyä tietoa.

Kirjalliset väärennökset jakautuu väärennösten, plagiaattien ja identiteettihuijausten yleiseen esittelyyn sekä eurooppalaisen ja suomalaisen kirjallisuuden tapausesimerkkeihin. Teoksen ensimmäinen osa määrittelee väärennöksen ja plagiaatin käsitteet ja niiden suhteet muuhun tekstienvälisyyteen. Ensimmäisessä osassa esitellään myös väärennösten tutkimusta, esimerkiksi tyylimetristä analyysia ja tekstin materiaalin alkuperän tutkimusta.

Eurooppalaisina tapausesimerkkeinä tuodaan esiin Oscar Wilden kuoleman jälkeen ilmestyneet meediohuijarit ja käsikirjoituskauppiaat, James Macphersonin Ossianin laulujen (1765) ongelmallinen suhde gaelinkieliseen kansanrunouteen ja ruotsalaisen Fabian Kastnerin postmodernistisen romaanin Oneirine. Roman i tusen delar (2006) tuhannet muunnellut sitaatit. Suomalaisen kirjallisuuden plagiointi- ja huijauskeskusteluista teos nostaa esiin V. A. Koskenniemen runojen likeisen suhteen eurooppalaisiin esikuviinsa, Mauri Sariolan veijarikirjailijuuden, Tuula Sariolan teosten pulmallisen tekijyyden sekä Anja Kaurasen Pelon maantieteen (1995) plagiointikohun.

Kaurasen teos on erityinen teoksen muun aineiston joukossa siinä, että Kaurasta syytettiin tieteellisten tekstien luvattomasta siteeraamisesta. Kaurasen teoksen vastaanoton analyysi paljastaa, miten teoksesta käyty kirjallisuuskeskustelu voi juuttua yhdelle raiteelle, tässä tapauksessa plagionnin spekulaatioon. Teosta ei aluksi luettu kollaasiromaanina, joka parodioi muiden diskurssien ohella radikaalifeminististä puhetta ja yhdistelee kollaasimaisesti 
sitaatteja tieteellisistä, kaunokirjallisista ja tietokirjallisuuden teksteistä, vaan plagiaattina, joka väärinkäyttää feminististä tutkimusta ja sen terminologiaa. Teoksen feministinen, sukupuolittunutta vallankäyttöä ja pelkoa koskeva sanoma jäi osin sitaattikeskustelun jalkoihin. Osa lukijoista ja kirjallisuusinstituution toimijoista kuitenkin puolusti Kaurasen teosta vetoamalla kaunokirjallisen tekstin tutkimustekstistä poikkeavaan viittauskäytäntöön.

Kirjalliset väärennökset ei paljasta niinkään väärennettyjä teoksia - kaikista käsitellyistä teoksista on keskusteltu pitkään ja hartaasti jo aiemmin - vaan pikemmin kirjallisuusinstituution heikkoja kohtia. Tapausesimerkit näyttävät kirjallisuusinstituution vaatteettomat keisarit. Nyqvist ja Oja esittävät perustellen, kuinka kriitikot, tutkijat ja muut kirjallisuuden lukijat voivat olla haluttomia tunnustamaan ihailemansa teoksen väärennettyä luonnetta ja toisaalta tuntevat kokeneensa suurta vääryyttä huijausten paljastuttua. Huijauksen paljastaja saattaa joutua syntipukiksi huijaajan sijasta. Suhtautuminen huijauksiin tuo esiin muitakin kiusallisia ja kiinnostavia teosten vastaanottoon liittyviä seikkoja. Miksi kanonisoidun kirjailijan tuotannon osana teos otetaan kiittäen vastaan, mutta tuntemattoman tekijän laatimana sama teos ei saa kiitosta eikä kunniaa? Miksi toisen kielialueen tai aikakauden kirjallisuuden plagiointia pidetään hyväksyttävämpänä kuin oman kielialueen aikalaiskirjallisuuden luvatonta lainaamista? Miksi on niin vaikeaa tuoda esiin eriävää mielipidettä kirjallisessa keskustelussa, joka toistaa yhtä tulkintaa? Ojan ja Nyqvistin teos ei vain kysy vaan myös vastaa näihin kysymyksiin.

Kirjalliset väärennökset on oiva teos tekstienvälisistä suhteista kiinnostuneille esitellessään väärennöksen ja plagioinnin suhteita muihin tekstienvälisyyden lajeihin, kuten adaptaatioon, appropriaatioon ja kollaasiin. Adaptaation ja appropriaation suhteesta luvattomaan lainaamiseen olisin mielelläni lukenut enemmänkin, varsinkin, kun adaptaatio ja appropriaatio ovat nykyisessä kulttuurikeskustelussa usein toistuvia mutta merkitykseltään monimuotoisia käsitteitä. Esimerkiksi Ossianin lauluja ja Kalevalaa voisi tulkita myös kulttuurisen appropriaation eli omimisen käsitteen avulla. Osa teoksista yhdistetään Kirjallisissa väärennöksissä yllättävästi fanifiktioon. Tämä vaikuttaa anakronistiselta, jos fanifiktio nähdään fanien omilla foorumeillaan julkaisemana epäkaupallisena uudelleenkirjoituksen muotona. On kuitenkin kiehtova ajatus, että Johan Ludvig Runebergin runoelman Kung Fjalar (1844) voisi lukea Ossianin laulujen fanifiktiona.

Teoksessa selvitetään Oscar Wilden tuotannon moninkertaista interteksuaalisuutta. Wilden omissa teoksissa on runsaasti lainauksia muilta kirjoittajilta, minkä vuoksi hän joutui itse plagiointiepäilyn kohteeksi. Toiset kirjoittajat ovat puolestaan yrittäneet jäljitellä hänen tyyliä̈n ja julkaista teoksia hänen nimissään. Fabian Kastnerin Oneirine on kiinnostava siksi, että sen voi lukea joko postmodernistisena intertekstuaalisuudella leikittelevänä kollaasiromaanina tai aiempien merkkiteosten härskinä siteeraamisena ja plagioimisena. 
Kastnerin Oneirine sai pääosin kiittävän, jopa ylistävän vastaanoton. Kirjallisuuden professori ja kriitikko Ivo Holmqvist kuitenkin syytti Kastneria Georges Perecin novellin "Talvinen matka" (1979) juonen ja henkilöhahmojen plagioinnista ja ehdotti julkaistun painoksen tuhoamista. Holmqvistin artikkeli sytytti kirjasodan, jossa syytetyksi nousi - kuinka ollakaan - pölyiseksi leimattu professori Holmqvist. (KV, 189-190.) Osa lukijoista tulkitsi Oneirinen postmodernia lainaamisen estetiikkaa noudattavana teoksena. Kirjailija itse puolusti tätä näkemystä julkaistessaan esseen "Jag steker upp gamla rester" (2006), jossa hän esittelee kirjoitusperiaatteitaan. Kastner kertoo lainanneensa tuhannesta vanhasta teoksesta, jotka ovat vaarassa unohtua pölyisten kirjastojen hyllyihin. Teoksen kustantajan Bonnierin tiloissa oli kaiken lisäksi näyttely, jossa yleisö saattoi tutustua Kastnerin muunnellen siteeraamaan tuhanteen teokseen. Nyqvist kritisoi oikeutetusti Kastnerin väitettä unohdetun kirjallisuuden henkiin herättämisestä. Teokset, joita Oneirinessa lainataan, ovat länsimaissa kanonisoituja miesten kirjoittamia teoksia, joita luetaan ja tutkitaan paljon. Nyqvistin sanoin "kierrättämällä vaikutteita 1900-luvun mieskirjallisuuden suurnimiltä Kastner onnistuu 2000-luvulla luomaan teoksen, joka tuntuu tunkkaisella tavalla edellisen vuosisadan tuotteelta" (KV, 212).

Kirjalliset väärennökset osoittaa, miten käsityksemme tekstistä ei yleensä perustu pelkkään tekstiin, vaikka tekstilähtöisyyttä usein painotetaan kirjallisuudenopetuksessa ja -tutkimuksessa. Tekijän nimi ja tekijän teosten vastaanotto vaikuttavat siihen, miten teos arvotetaan ja miten sitä tulkitaan. Nyqvistin ja Ojan mukaan "[m]ielikuvat teoksesta eivät siis perustu vain tekstiin vaan myös siihen, miten sitä luokitellaan ja millaisin käsittein siitä puhutaan" (KV, 51). Nyqvistin ja Ojan teos näyttää, miten kirjallisuuden vääryydet ovat usein suhteellisia. Joissain lajeissa ja konteksteissa merkitsemättömien sitaattien käyttö on hyväksyttävämpää kuin toisissa. Kirjallinen huijaus voi olla satiirinen taideteos, joka paljastaa kirjallisuusinstituution vaiettuja puutteellisuuksia.

Vertailu Carolyn Keenen Neiti Etsiviin ei tuo Nyqvistin ja Ojan tyylille täyttä oikeutta, mutta heidän kirjoittamansa teoksen yhdistää Paula Drewn seikkailuihin johtolankojen analyysin lisäksi se, että luvun lopussa lukijaa jännittää, millaisia mysteerejä seuraavassa luvussa ratkotaan. Kirjalliset väärennökset punoo tarkkaa tekstianalyysia kirjallisen kontekstin, vastaanoton ja kirjallisuudenlajien analyysiin. Tämän vuoksi teos on harvinaisen monipuolinen ja soveltuu oppikirjaksi esimerkiksi kirjallisuusinstituutiota tai intertekstuaalisuutta käsitteleville kursseille. Aiheeltaan kiehtova, hyvin kirjoitettu ja kirjallisuustieteelliset termit selkeästi määrittelevä teos sopii luettavaksi myös kirjallisuudentutkijoita huomattavasti laajemmalle yleisölle.

\section{Hanna Samola}

